\title{
ISOLATION AND IDENTIFICATION OF NATIVE EGYPTIAN CURDLAN PRODUCING AGROBACTERIUM ISOLATE
}

\author{
${ }^{1}$ El-Sehemy I.A., ${ }^{2}$ Haroun B.M., ${ }^{1}$ El-Diwany A.I., ${ }^{1}$ EI-Shahed K.Y., ${ }^{1}$ Awad H.M., and \\ ${ }^{3}$ Tolba I.H.
}

${ }^{1}$ Chemistry of Natural and Microbial product Dept., Pharmaceutical industry Dev., National Research Centre Dokki, Cairo, Egypt.

${ }^{2}$ Botany and Microbiology Department, Faculty of Science, Al-Azhar University, Nasr City, Cairo-Egypt.

${ }^{3}$ Plant Pathology Branch, Agricultural Botany Department, Faculty of Agriculture, Al Azhar University, Cairo, Egypt.

\begin{abstract}
One hundred and eighty bacterial isolates were isolated from different soil samples and different crown galls from some plants (grape, apple, peach) grown in Egyptian soil in different area. Gram stains were applied on all isolates and the results showed that 120 isolates were Gram negative and 60 strains were Gram positive. The Gram negative isolates were selected for pathogenicity tests and were used to infect some hosts (grape, tomato and kalanchoe). The results showed that about 60 isolates cause infections of the above mentioned plants, these isolates were subjected to grow on some selective media as aniline blue medium and Congo red medium to detect curdlan producer isolates. The results obtained indicated that seven isolates give positive reaction toward curdlan production, three isolates were selected for production of curdlan after some chemical analysis and the most potent isolate was selected for optimization and identification. The potent isolate have been identified by morphological, biochemical and phylogenetic analyses.
\end{abstract}

Kew words: Isolation, Screening, Identification, Agrobacterium and curdlan

\section{INTRODUCTION}

Microbial polysaccharides have many practical applications in various industries as food, pharmaceutical, medical technology and cosmetics. In the last two decade there has been an expanding interest in polysaccharides produced extracellularly by microorganisms, many new researches have been focused on the use of microbial polysaccharides (including curdlan), in food, pharmaceutical, and medical industry (Moscovici et al., 2009).

Curdlan is the third microbial exopolysaccharide approved for use in the United States by the FDA, which was approved in 1996 (USFDA, 1996). Curdlan is biodegradable, edible and nontoxic toward humans and the environment; in addition to the application in food, pharmaceutical industries, cosmetic industry, and numerous other applications, such as antiviral and anticancer treatments (McIntosh et al., 2005). Curdlan is produced by many species of Agrobacterium, Rhizobium and Alcaligenes faecalis var. myxogenes (Nakanishi et al., 1976).

Agrobacterium is one of the most attractive sources of polysaccharides and other biologically active substances of high value and medicinally useful polysaccharides (Mellouli et al., 2003). The genus Agrobacterium belongs to the family Rhizobiaceae (Jordan, 1984). These bacteria are Gram-negative and grow aerobically, without forming endospores. The cells are rod-shaped and motile, having one to six peritrichous flagella. Cells are 0.6-1.0 $\mu \mathrm{m}$ by $1.5-3.0 \mu \mathrm{m}$ and may exist singly or in pairs. In culture on carbohydrate-containing media, 
cells produce large amounts of extracellular polysaccharides, giving colonies a voluminous, slimy appearance (Moore et al., 1988).

A comprehensive screening of the occurrence of microbial curdlan-like polysaccharides based on the formation of blue-staining colonies on agar medium containing the $\beta(1 \rightarrow 3)$-D-glucan specific dye, aniline blue, was made by (Nakanishi et al., 1976). Agrobacterium can be isolated from tumors, vascular fluids, soil, water, and below-ground surfaces of symptomless plants (Moore $\boldsymbol{e t}$ al., 1988). Colonies of microorganisms capable of forming curdlan - type polysaccharide in glucose medium were found to stain blue with Aniline blue, trypan blue or Brilliant blue and red with Congo red. Staining with aniline blue was highly specific for colonies forming curdlan-type polysaccharide (Nakanishi et al., 1974).

DNA-based methods such as DNA:DNA hybridization (Ley, et al., 1973). Sequence analysis of $16 \mathrm{~S}$ rDNA and $23 \mathrm{~S}$ rDNA (Willems, and Collins, 1993) is a good tool in taxonomy of Agrobacterium, so the proper identification should be used by traditional identification in combination with molecular methods. The molecular genetics of curdlan production have been studied extensively in Agrobacterium sp. (Stasinopoulos, et al., 2001).

Over 100 tons of Curdlan are produced annually even though curdlan is relatively expensive in comparison to other food gums (Chaplin, 2003). So that now, it is an urgent need in Egypt to isolate new microbial curdlan-like polysaccharides and develop production fermentation technology for the production of this type of polysaccharide.

The aim of our study was undertaken to isolate new Agrobacterium strains produced curdlan-like polysaccharides, from different locations in Egypt. The isolated strains were identified using different techniques and their potential for curdlan production was determined.

\section{MATERIALS AND METHODS:}

\section{Sampling procedure:}

\section{Isolation of Agrobacterium from the farming soil samples.}

Ten farming soil samples were collected in clean plastic bags at depth $15-20 \mathrm{~cm}$ from different localities in Egypt (Alexandria, EL-Sharkia, Qualiubia, Cairo and Giza). The collected soil samples were air dried and pre-treated in various ways to increase their contents of numbers and/or proportion of Agrobacterium before the isolation processes according to Tsao et al (1960). The samples were collected from the rhizosphere of some plants (Apple, Bean, Grapes, peach and ficus).

Isolation and enumeration of Agrobacterium were performed by soil dilution plate technique using either nutrient agar or Roy-Sasser medium. One gram of dried soil was taken in $9 \mathrm{ml}$ of distilled water, shaking it well then allowed to stand for $10 \mathrm{~min}$, serial dilutions were carried out for each sample from $10^{-1}$ to $10^{-7}$ Only $0.1 \mathrm{ml}$ of different aqueous dilutions $\left(10^{-3}, 10^{-5}\right.$ and $\left.10^{-7}\right)$ was transferred to RS medium in Petri dishes and spread by a glass spreader under aseptic conditions and then incubated for 4 to 5 days at $28-30^{\circ} \mathrm{C}$. Selected colonies (mucoid, rough, chalky) of Agrobacterium were transferred separately from the plates onto another respective agar plates and incubated at $28^{\circ} \mathrm{C}$ for 5 days. Plates containing pure cultures were stored until further examinations (Oskay et al., 2004).

\section{Isolation of Agrobacterium from tumor and crown gall samples:}

Twenty tumor and crown gall tissue were collected in a sterilize container from different dicot plants apple, grapes, peach and ficus, after collection samples were immediately transferred to the laboratory for necessary action and special cares were taken to 
avoid contamination. After cleaning the collected samples, the galls were sterilized with (10\%) household bleach (Savlon) for 2-3 min according to the nature of the galls. After washing three more time with double-distilled water (DDW), galls were finely chopped and immersed in DDW and incubated overnight at room temp $\left(27-30^{\circ} \mathrm{C}\right)$. Treated tissues were dried on absorbent paper toweling before being placed on agar to reduce the amount of bacterial contamination (Nelson $\boldsymbol{e t}$ al., 1983). Representative colony were selected from each gall sample and purified by successive streaking (Soriful et al., 2010).

Roy- Sasser medium was used as a selective medium for Agrobacterium which composed of $(\mathrm{g} / \mathrm{l}): \mathrm{MgSO}_{4} .7 \mathrm{H}_{2} \mathrm{O}, 0.2 ; \mathrm{K}_{2} \mathrm{HPO}_{4}, 0.9 ; \mathrm{KH}_{2} \mathrm{PO}_{4}, 0.7$; Adonitol, 4.0; Yeast extract, 1.4; $\mathrm{NaCl}, 0.2$; boric acid, 1.0; Agar, 20.0. The $\mathrm{pH}$ was adjusted to 7.2 before sterilization. After cooling to $50^{\circ} \mathrm{C} 1 \mathrm{ml}$ of the following sterilized solution was added under aseptic condition to each Petri dish. The solution consists of the following ingredients: (Triphenyltetrazolium chloride $80 \mathrm{mg} / \mathrm{l}$ or D- cycloserine $20 \mathrm{mg} / \mathrm{l}$ or Trimethoprim $20 \mathrm{mg} / \mathrm{l}$ ) (Roy and Sasser, 1983).

\section{Screening of curdlan- like polysaccharide with aniline blue and Congo red.}

Colonies of microorganisms capable of forming curdlan- type polysaccharide in glucose medium were found to stain blue with aniline blue, brilliant blue, or trypan blue and red with Congo red. Staining with aniline blue was high specific for colonies forming curdlan- type polysaccharide (Nakanishi et al., I 976).

$\mathrm{AB}$ (Aniline blue) medium was used as a selective medium for curdlan- like polysaccharide and used to detect colonies forming curdlan because aniline blue combines specifically with curdlan. $\mathrm{AB}$ medium composed of $(\mathrm{g} / \mathrm{l})$ : ) Glucose 10; yeast extract, 5; aniline blue, 0.05; agar, 20; $\mathrm{pH} 7.2$, and, $\mathrm{CaCO}_{3} 3.0$, was added to neutralize the medium during incubation, because a $\mathrm{pH}$ range of 5 to 7 is required for agequate staining with aniline blue (Nakanishi et al., I 974).

\section{Identification of active Agrobacterium isolate.}

Conventional identification:

Morphological and cultural characteristics:

Agrobacterium colonies were characterized morphologically and physiologically according to Bergey's manual of determinative bacteriology (Moore, et al., 1988). Cultural characteristics of pure isolates in various media were recorded. Morphological observations were made with light microscope, phytopathogenic properties; biochemical features to differentiate the biovar were studied (Holmes, 1988).

\section{Physiological and biochemical characteristics:}

Identification of Agrobacterium isolates based on physiological characteristics such as aniline blue test, Congo red test, growth in glucose peptone agar, reaction of litmus milk, growth on potato dextrose agar (PDA), 3-ketolactose test, and sodium chloride tolerance test (Murugesan et al., 2010) was carried out and then confirmed by the pathogenicity test i.e., crown gall or hairy root formation (Murugesan et al., 2010). Pathogencity tests were done using hosts as, tomato, kalanchoe and grape (Chen et al., 1999, Aysan et al., 2003). The ability of presumptive Agrobacterium to cause crown gall was examined by stem prick inoculation of 6-week-old tomato and kelncho, 15-cm-high weeping grape and fig plants kept in a growth chamber at $28^{0} \mathrm{C}$. Tumor formation was assessed 6 to 8 weeks after inoculation. Hou et al., (1996) reported that, biolog GN microstation is very useful in identification of Agrobacterium.

\section{Phylogenetic identification:}

\section{Chromosomal DNA isolation:}

Isolated Agrobacterium sp NRC-6 was inoculated in $50 \mathrm{ml}$ of the LB (Luria-Bertani) broth medium and inocubated at $28^{\circ} \mathrm{C}$ with agitation speed $200 \mathrm{rpm}$ overnight. Chromosomal 
DNA for PCR applications was isolated from Agrobacterium using Axyprep bacterial genomic DNA extraction kit from AxyGEN Biosciences according to the manufacturer's instructions. The concentration of a solution DNA can be determined by measuring the absorbance of at O.D 260 using a spectrophotometer where 1.0 is equivalent to a concentration of $50 \mu \mathrm{g} / \mathrm{ml}$, Oligonucleotides were ordered commercially from Sigma Company.

\section{PCR amplification and detection of DNA.}

Amplification using Agrobacterium- specific (PCR) primers were performed on BioRad PCR thermal cycle, to amplify the 16SrRNA gene from Agrobacterium sp a set of nucleotide sequences of the PCR primers were chosen from the DNA sequence of the Agrobacterium sp EHA105 accession number: EU835736 taken from the website of the national center of biotechnology information (NCBI). The primers are F1:5'ATGTATTTCAGTGCTGAAGGTGACG3'andF2:5'TCACCCGAATGCCCGTGCG 3'.

\section{DNA manipulation and analysis}

Electrophoresis of the PCR product was carried out on $1 \%$ agarose gel to ensure that a fragment of the correct size had been amplified. DNA was routinely mixed with gel loading buffer and run on $1 \%(\mathrm{w} / \mathrm{v})$ agarose gel as appropriate, using $1 \mathrm{x}$ Tris borate buffer (T.B) as the running buffer (Sambrook et al., 1989). The electrophoresis was carried out at 80 volt in the small gel tank. The DNA in the gel was visualized by staining with ethidium bromide and detected by gel documentation system (Alpha- imager 2200, CA, USA), under U.V light. The molecular weight markers; $100 \mathrm{bp}, 1 \mathrm{~kb}$ (Biosciences) were used to estimate the size of the DNA fragments. All enzymes used in DNA manipulations were supplied by Promega company and were used according to the manufacturer's instructions. The PCR products were purified using gene clean kit (AxyGEN Biosciences) and outsourced for sequencing to the gene analysis unite by lab technology company.

\section{Phylogenetic analysis of the PCR products:}

Nucleotide sequences were compared with those maintained in the gene bank database through NCBI Blast program (Altschul et al., 1990). For Phylogenetic analysis, sequences were aligned with those of reference strains with the program BioEdit version 7.0 ( Hall, 1999). The phylogenetic tree was derived from the distance matrices using neighbor - joining method (Saitou and Nei, 1987).

\section{Culture condition for curdlan production.}

The seed cells of each Agrobacterium isolate were cultivated on nutrient broth (Difco,USA) at $30^{\circ} \mathrm{C}$ for $12 \mathrm{~h}$. Ten milliliters of seed culture was inoculated into $1 \mathrm{~L}$ of mineral salt medium (MSM; g per L; 1.74, $\mathrm{KH}_{2} \mathrm{PO}_{4}, 0.015, \mathrm{CaCl}_{2} \cdot 2 \mathrm{H}_{2} \mathrm{O}, 0.49, \mathrm{~K}_{2} \mathrm{HPO}_{4}, 0.01$, $\mathrm{MnCl}_{2} .4 \mathrm{H}_{2} \mathrm{O}, 3.7, \mathrm{Na}_{2} \mathrm{SO}_{4} .10 \mathrm{H}_{2} \mathrm{O}, 0.21$, citrate, $0.25, \mathrm{MgCl}_{2} .6 \mathrm{H}_{2} \mathrm{O}, 1.5, \mathrm{NH}_{4} \mathrm{Cl}, 0.024$, $\mathrm{FeCl}_{3} \cdot 6 \mathrm{H}_{2} \mathrm{O}$. that was supplemented with $3 \%$ sucrose as a carbon source to induce curdlan production and cultured at $30^{\circ} \mathrm{C}$ for 4 day with shaking at $200 \mathrm{rpm}$.

\section{Extraction of curdlan from cultural media:}

Extraction and isolation of curdlan was carried out adding one volume of culture media with two volumes of $\mathrm{NaOH}(1 \mathrm{~N})$. The mixture was kept for $1 \mathrm{~h}$ at room temperature. To remove degraded bacterial cells the mixture was centrifuged at $4000 \mathrm{rpm}$. The supernatant was neutralized with $\mathrm{HCl}(3 \mathrm{~N})$ to $\mathrm{pH}$ 5-7: After keeping the mixture at $2-8^{\circ} \mathrm{C}$ for overnight, the curdlan was obtained by centrifugation at $4000 \mathrm{rpm}$. The residue was washed with distilled water several times to remove salts from residue and finally washed with acetone to furnish dry product and stored at room temperature until further use (Lee et al., 1997). 


\section{Determination method of curdlan:}

Complete acid hydrolysis of samples was carried out according to the modified method of (Fischer and Dorfel, 1955) as follows:

$50 \mathrm{mg}$ of the investigated material were carefully stirred with $0.5 \mathrm{ml}$ of ice cold $80 \%$ $\mathrm{H}_{2} \mathrm{SO}_{4}$ to give a paste and was kept at room temperature for $15 \mathrm{hr}$. The paste was then diluted with cold distilled water (up to $6.5 \mathrm{ml}$ ) until the strength of the sulphuric acid reached $2 \mathrm{~N}$. The solution was further hydrolyzed in a sealed tube in a boiling water bath for $6 \mathrm{hr}$. After cooling, the hydrolyzed was neutralized by addition of the calculated amount of $\mathrm{BaCO}_{3}$. The precipitate was filtered and thoroughly washed with water. The filtrate and washing were passed through a column of cation exchange resin, Amberlit IR120 $\left(\mathrm{H}^{+}\right)$. The resulted solution was concentrated and then subjected to qualitative and quantitative paper chromatography as follows:

\section{Chromatographic examination of the hydrolysis products:}

This was performed by paper chromatographic technique of the hydrolysate on Whatman No. I filter paper using the solvent system: n-butnol-acetone-water $(4: 5: 1$, v/v) (Jayme and Knolle, 1956). For a comparison, authentic samples of glucose, galactose, arabinose and xylose were co-chromatographed as reference substances. Detection of spots was achieved by spraying with an aniline-phthalate reagent (Partridge, 1949).

\section{RESULTS AND DISCUSSION}

This study was undertaken with an aim of high lighting on selecting strains curdlan- like polysaccharide producer.

\section{Sampling procedure:}

One hundred and eighty bacterial isolates were isolated from 20 tumor and crown gall samples (Apple, grapevine and ficus) and 10 soil samples collected from different area in Egypt table (1).

Table (1): Location of the collected samples

\begin{tabular}{||c|c|c|c|c||}
\hline No. & Origin of samples & $\begin{array}{c}\text { No of } \\
\text { isolate }\end{array}$ & $\begin{array}{c}\text { Gram } \\
\text { stain }\end{array}$ & $\begin{array}{c}\text { Sample } \\
\text { characteristic }\end{array}$ \\
\hline $\mathbf{1}$ & Giza (( alauad, kardasa) & 25 & $\begin{array}{c}7+\mathrm{ve} \\
18-\mathrm{ve}\end{array}$ & $\begin{array}{c}\text { cultivated soil, } \\
\text { apple gall) }\end{array}$ \\
\hline $\mathbf{2}$ & Egypt (Ezbet El_Nakhal) & 15 & $\begin{array}{c}5+\mathrm{ve} \\
10-\mathrm{ve}\end{array}$ & $\begin{array}{c}\text { (cultivate soil) } \\
\text { (Apple, ficus } \\
\text { tumors) }\end{array}$ \\
\hline $\mathbf{3}$ & Alexandria (nobaria) & 45 & $\begin{array}{c}15+\mathrm{ve} \\
30-\mathrm{ve}\end{array}$ & $\begin{array}{c}\text { (cultivate soil) } \\
\text { (Apple, ficus, } \\
\text { peach tumors) }\end{array}$ \\
\hline $\mathbf{4}$ & Qualiubia (Benha) & 35 & $\begin{array}{c}18+\mathrm{ve} \\
17-\mathrm{ve}\end{array}$ & $\begin{array}{c}\text { cultivated soil } \\
\text { (Grapevine) }\end{array}$ \\
\hline $\mathbf{5}$ & EL-Sharkia (ZakaZig) & 35 & $\begin{array}{c}4+\mathrm{ve} \\
31-\mathrm{ve}\end{array}$ & $\begin{array}{c}\text { (cultivated soil) } \\
\text { ficus, grape gall }\end{array}$ \\
\hline $\mathbf{6}$ & EL- Mansoura (Dekarns) & 25 & $\begin{array}{c}11+\mathrm{ve} \\
14-\mathrm{ve}\end{array}$ & $\begin{array}{c}\text { (cultivated soil) } \\
\text { apple, grape gall }\end{array}$ \\
\hline Total & \multicolumn{1}{|c|}{$\begin{array}{c}60+\mathrm{ve} \\
120-\mathrm{ve}\end{array}$} & \\
\hline \hline
\end{tabular}


Agrobacterium grow readily in culture on complex or defined media and nutrient agar (with or without yeast extract which support the growth of most strains. Only one type of colony was detected in plates. On RS medium, colonies of Agrobacterium have dark red centers with white edges. In RS medium triphenyltetrazolium chloride was used as a primary indicator for Agrobacterium isolation (Roy and Sasser, 1983).

The isolated colonies are generally white or slightly cream, and have a watery appearance. These results were in agreement of Moore et al., (1988), who found that the colonies of Agrobacterium are generally white or slightly cream or pale pink in color, no distinctive pigment is produced and large amounts of extracellular polysaccharide may be produced on some media giving the colonies a watery appearance figure (1).

(A)

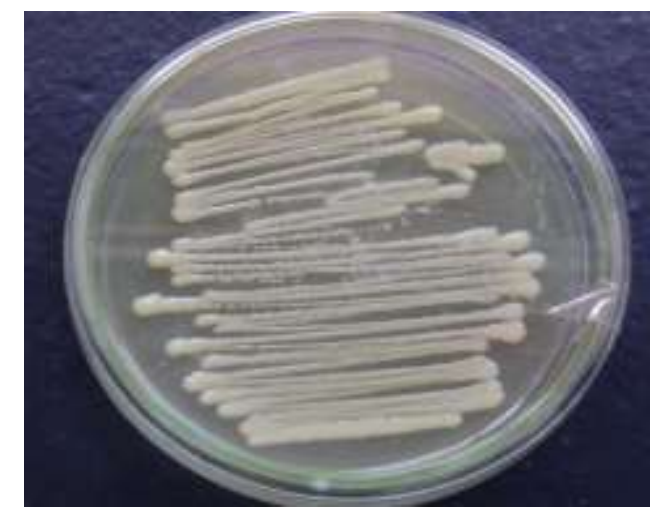

(B)

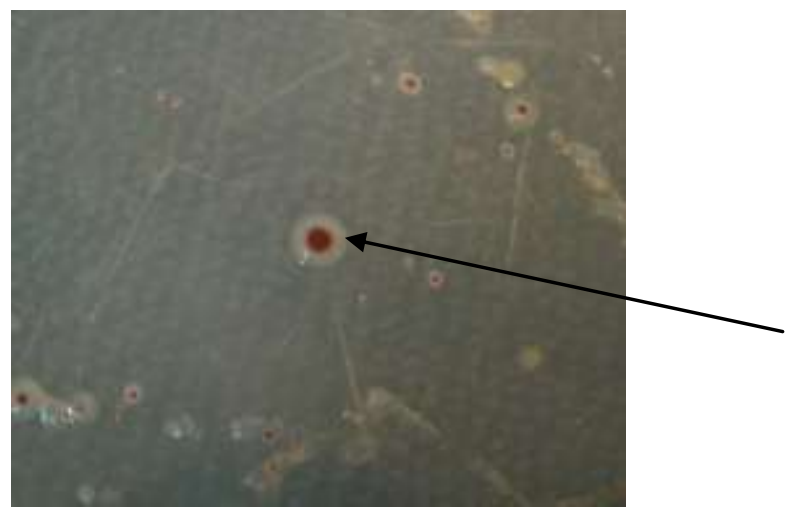

Fig. (1): (A) Pure culture of isolated Agrobacterium on PDA medium. , (B): Pure colony of isolated Agrobacterium on RS medium.

Gram stains were performed on all strains and the results showed that 120 strains were Gram negative and 60 strains were Gram positive. The Gram negative isolates were selected for pathogenicity tests according to the methods described by (Aysan et al., 2003).

About 60 strains exhibited tumor galls formation after 3 weeks approximately while the other bacterial isolates failed to form galls. From these results, the selected colonies which have ability to infect plants and produce galls figure (2), this main that these bacteria found to belong to Agrobacterium. Agrobacterium usually are found in soil in association with roots, tubers, or underground stems. The bacteria also cause tumors from which they can be isolated. Tumors may be prevalent on grafted plants at the graft junction; examples include grapes, roses, poplars, and fruit trees. In some cases, the bacteria can be isolated from the xylem of infected plants. Thus it is often possible to isolate A. vitis from the xylem of infected grapevines (Bouzar and Moore 1987). The isolation of Agrobacterium and Conventional disease diagnosis based on cultivation on selective or non selective media (Moore $\boldsymbol{e t}$ al., 1988) followed by inoculation of the colonies obtained in herbaceous hosts such as tomato or tobacco (Moore et al., 1988; Lopez 1991). 


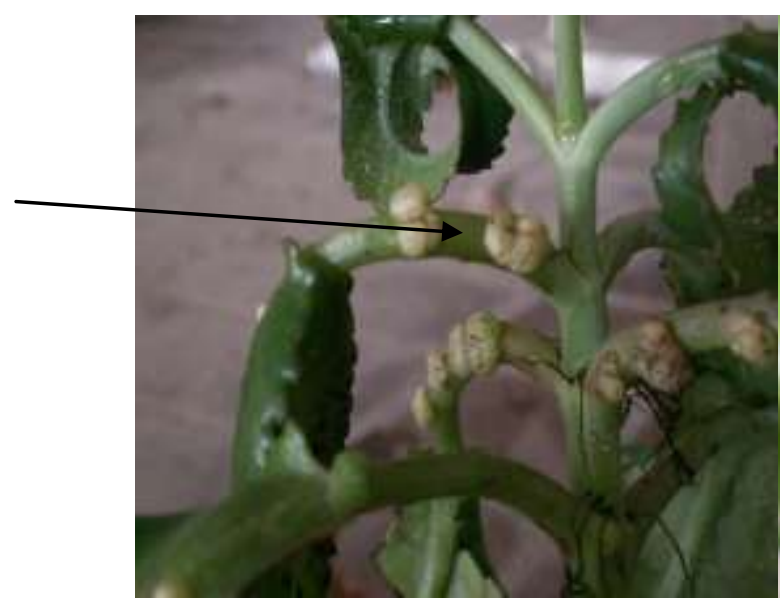

(A) kalanchoe plant

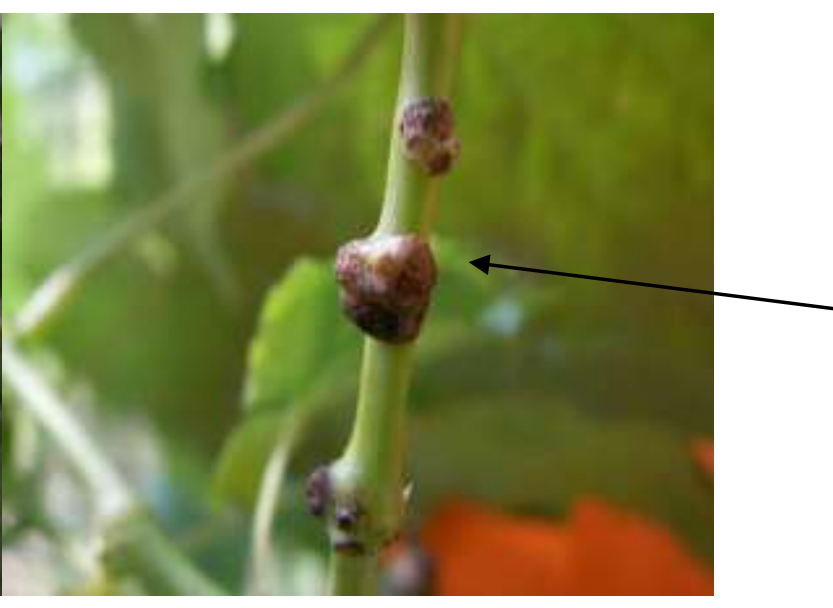

(B) grape plant

Fig (2): Inoculated Agrobacterium exhibite tumor galls formation after 3 weeks approximately

\section{Screening of curdlan- like polysaccharide with aniline blue and Congo red.}

Among 60 isolates which were selected from pathogenicity tests, seven isolates give positive reaction blue with aniline blue media, red with congo red media and no positive reaction was detected in other isolates as shown in the following fig (3). Harada et al., (1966), found that aniline blue is much more suitable than congo red or other dyes for detecting curdlan - type polysaccharide in colonies, since it specifically stains beta $(1,3)$ glucans, such as curdlan - type polysaccharide. Nakanishi et al., (1974), showed that staining with aniline blue is specific for beta ( 1-3) glucans including curdlan - type polysaccharide, while trypan blue, brilliant blue or Congo red stain many kinds of polysaccharides, colonies forming curdlan type polysaccharide were found to stain clearly with all dyes, also found that the rate of interaction of polymer with dye was proportional to the concentration, degree of polymerization and gel- forming ability of curdlan- like polysaccharide.

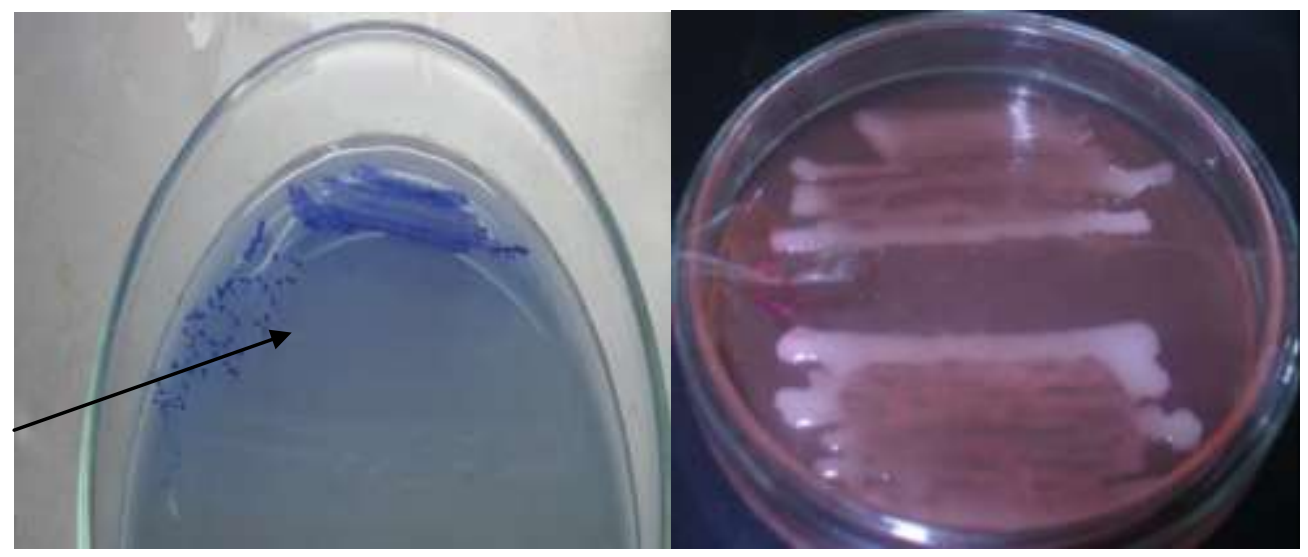

Fig (3): (A) Isolated Agrobacterium on $\mathrm{AB}$ medium, (B) Isolated Agrobacterium on congo red medium.

\section{Chromatographic examination of curdlan production.}

Seven isolates which give positive reaction selected for curdlan production and cultivated on MSM medium supplemented with $3 \%$ sucrose as a carbon source to induce 
curdlan production at $30^{\circ} \mathrm{C}$ for four days with shaking at $200 \mathrm{rpm}$ then curdlan extraction process was carried out.

Among seven isolates three isolate give glucose unit, chemical analysis of curdlan product was carry out, The sugar composition of curdlan produced by isolates was examined by descending paper chromatography after hydrolyzing with acid. The hydrolysate of glucan produced by isolate (no.2R2, 6, Dy) gave one spot with an Rf value of similar to the value of the glucose unit, figure (4). This implied that glucan isolate (No.2R2) is composed of glucose only. The same result was obtained with the strains numbers $(6$, Dy)

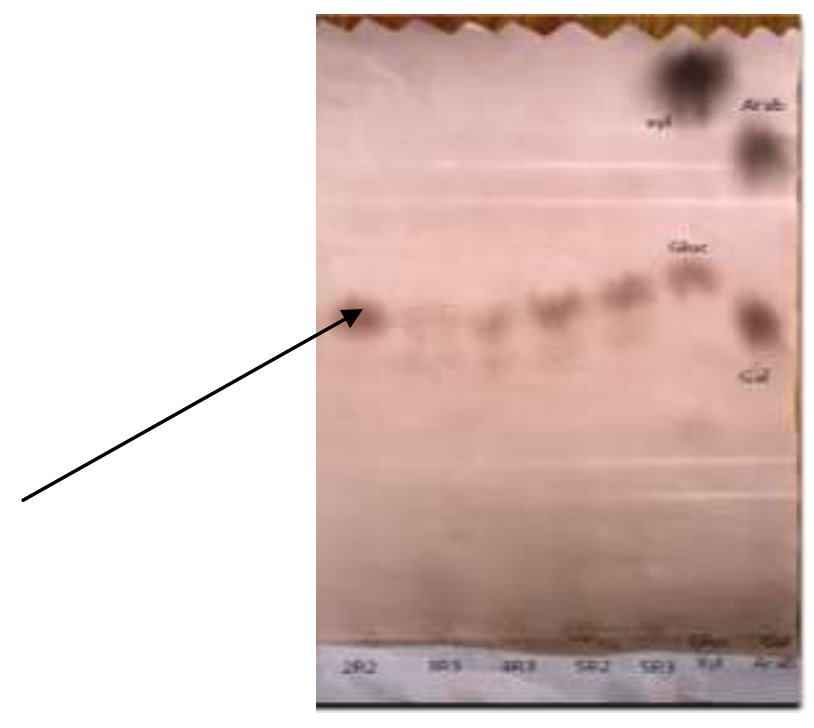

Fig. (4): Chromatographic examination of isolated products from the tested isolates and showed isolate no2 (2R2) produce curdlan.

One isolate was selected for curdlan production after some chemical analysis and selected for optimization and identification.

\section{Identification of the most potent isolate $\mathrm{NRC}$ - 6, producing curdlan polysaccharide.}

\section{A)- Conventional identification}

Morphological and cultural characteristics:

Of many soil and crown gall samples screened, we found the selected isolated bacteria are Gram-negative and grow aerobically, without forming endospores. The cells are rod-shaped and motile. In culture on carbohydrate-containing media, cells produce large amounts of extracellular polysaccharides giving colonies creamy, mucoid a voluminous, have a slimy appearance. This result compared with identification of Agrobacterium in laboratory guide for identification of plant pathogenic bacteria (Moore et al., 1988).

\section{Physiological and biochemical characteristics.}

We found the selected isolated bacteria give positive reaction blue with aniline blue, red with Congo red, staining with aniline blue and Congo red was highly specific for colonies forming curdlan-type polysaccharide (Nakanishi et al., 1974). Also the selected isolated bacteria give positive reaction with Growth in glucose peptone agar, growth on potato dextrose agar (PDA).Also the selected isolated bacteria identified by Biolog GN microstation, Fourty-four of the ninety-six wells of a Biolog GN microplate yielded positive results: Draffinose, D-glucose, D- sorbitol, Pectin, $\alpha$-D-Lactose, D-Mannose, D-Mannitol, DGalacturonic acid, D-Maltose, D-Melibiose D-Fructos, D-Arabitol, L-Alanine, D-Trehalose, B-Methyl-D-Glucoside, D-Galactos, myo-Inositol, D-Gluconic acid, D-Cellobios, D-Salicin, Glycerol, D-Glucuronic acid, Gentiobiose, N-Acetyl-D-Glucosamine, D-Fucose, L-Histidine, Propionic acid, Sucrose, L-Fucose, D-Fructose 6-PO4, L-Glutamic acid, D-Malic acid, D- 
Turanose, L-Rhamnose, L-Pyroglutamic acid, L-Malic acid, acetic acid, Stachyos, Formic acid, $1 \% \mathrm{NaCl}, \mathrm{pH}$ 6, Troleandomycin, Vancomycin, and Tetrazolium Blue. By comparison to known strains, the Biolog GN microstation identified isolate NRC- 6 as belonging to the genus Agrobacterium, and having a similarity to the closest species, A. rhizogenes and A. radiobacter. Similar results obtained by Hou et al., (1996), in identification of Agrobacterium DS3 NRRL B-14297. by Biolog GN microstation. Identification confirmed by the pathogenicity test which exhibit ability of the isolate to infect plants and produce crown galls.

\section{B)- Phylogenetic identification.}

Woese (1987) reported that, 16S rRNA gene sequences has been demonstrated to be a powerful method for investigating phylogeny of microorganisms. Also Kim et al., (2004) reported that $16 \mathrm{~S}$ rRNA is a powerful tool for phylogenetic analysis and species differentiation (differentiating unknown isolates at the species or strain level), and can be used as a genetic method in parallel to conventional taxonomic methods, including numerical, phenetic and other genetic analyses. Thus in our study phylogenetic analysis based on $16 \mathrm{~S}$ rRNA gene sequence of Agrobacterium isolates were partially sequenced.

Amplification of the 16S rDNA gene:

The 16S rDNA gene of the isolate NRC- 6 was amplified by Agrobacterium- specific (PCR) primers F1 (forward):5'atgtatttcagtgctgaaggtgacg3' and F2(reveres): 5'TCACCCGAATGCCCGTGCG 3'. The product of the PCR was analyzed on $1.5 \%$ ethidium bromide gel and showed a band at 1300 bp Fig. (5) The sequencing product of the isolate NRC- 6 was determined as 1098 bp.

The alignment of the nucleotide sequences (1098 bp) of Agro.sp. NRC- 6 in through matching with the 16S rRNA reported genes sequences in the gene bank database through NCBI Blast available at the ncbi-nlm-nih.gov Web site and compared with sequence of the reference species of Agrobacterium contained in genomic database banks. The high level of sequence similarity of the isolate Agro.sp. NRC- 6 was to Agrobacterium rhizogenes NGT471 accession number: AB289616.1 which has similarity (96\%).

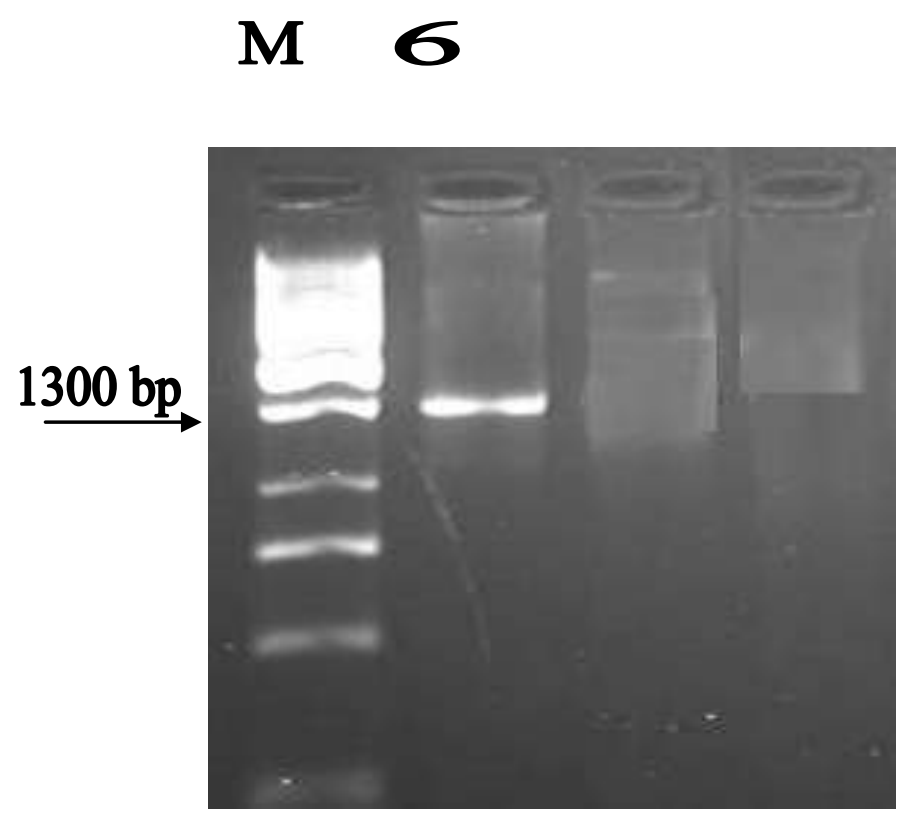

Fig. (5): PCR product of $16 \mathrm{~S}$ rDNA gene for the isolate NRC- 6; where (M) is the $100 \mathrm{bp}$ DNA ladder (marker). 


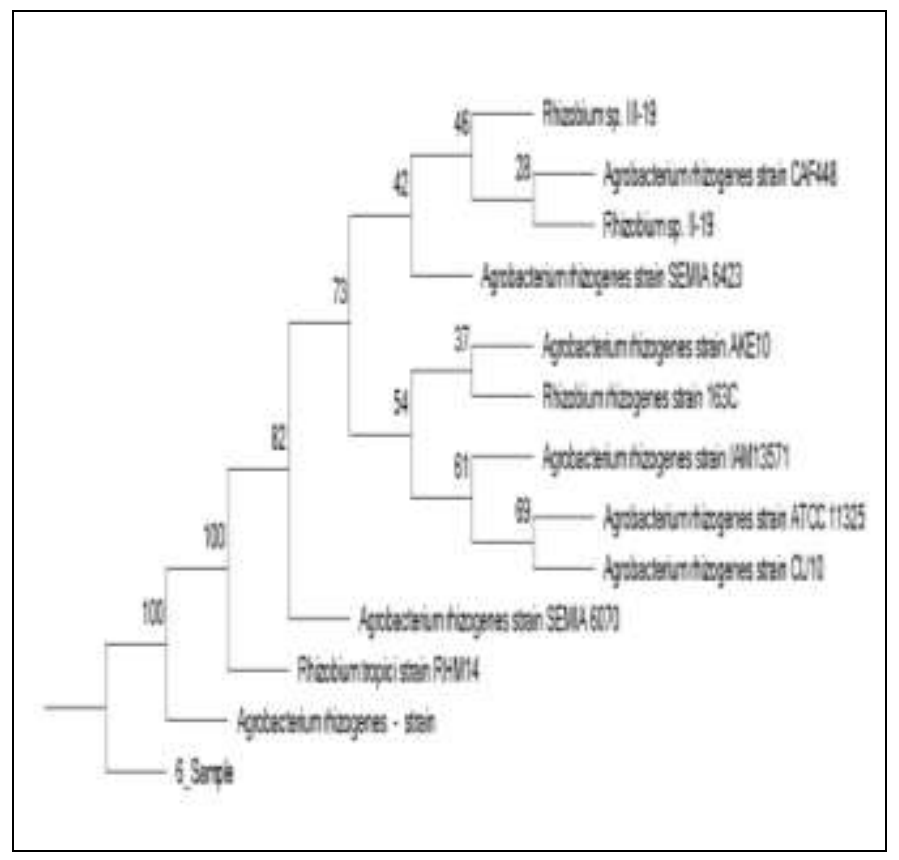

Fig. (6): Phylogenetic analysis neighbor-joining tree, represent the position of Agrobacterium species NRC-6 similar with known sequence in the gene bank database.

In conclusion, the results obtained from phylogenetic analysis, the morphological, and physiological characters of Agrobacterium species NRC-6 was found to match the character of Agrobacterium rhizogenes and for this, it was given a varity of this species and was named Agrobacterium rhizogenes - NRC-6.

\section{REFERENCES}

Altchul, S.F., Gish, W, Miller, W., Myers, E. W., and lipman, D.J. (1990): Basic local alignment search tool. J. Mol. Boil., 215: 403- 410.

Aysan Y., Sahin F., Mirik M., Donmez M. F. and Tekman H. (2003): First report of crown gall of apricot (Prunus armeniaca) caused by Agrobacterium tumefaciens in Turkey, Plant Pathology p. 793.

Bohn, J.A. and Be Miller, J.N. (1995): $\beta$ - (1, 3)-D-glucans as biological response modifiers: a review of structure-functional activity relationships Carbohydrate Polymer; 28:3-14.

Bouzar H., Moore L.W. (1987): Isolation of different Agrobacterium biovars from a natural oak savanna and tallgrass prairie. Applied and Environmental Microbiology 53: 717- 721.

Cabib, E., Bowers, B., Roberts, R.L. (1983): Vectorial synthesis of a polysaccharide by isolated plasma membranes. Proc. Natl Acad. Sci. USA 80, 3318-3321.

Chaplin, M. F., (2003): Fiber and water binding. Proceedings of the Nutrition Society Curdlan Gum, 62, 223-227.

Fischer, F.G. and Dörfel, H. (1995): Hoppe-Seyler`s Zeitschrift fur Physiol. Chem., 302, 186-203. 
Futatsuyama H, Yui T, Ogawa K (1999): Biosci, Biotechnol, Biochem 63:1481-1483.

Hall. T.A., (1999): Bioedita user- friendly biological sequence alignment editor and analysis program for windows 95-98. nucleic acid symp., ser., 41: 95-98.

Harada T, Harada A (1996): Curdlan and succinoglycan. In DumitriS (Ed) Polysaccharides in medical applications. Dekker, NewYork, pp 21-57.

Harada T. M Masada. K Fujimori and I Maeda. (1966): Production of a firm. resilient gelforming polysaccharide by a mutant of Alcaligenes faecalis var mycogenes IOC3. Agric Bioi Chem 30: 196-198.

Harada, T. (1965): Succinoglucan 10C3: a new acidic polysaccharide of Alcaligenes facecalis var. myxogenes, Arch. Biochem. Biophys. 112: 65-69.

Holmes, B. (1988): Taxonomy of Agrobacterium, Acta Hortic. 225 : 47-52.

Holt, J.G. Krieg, N.R. Sneath, P.H.A. Staley, J.T. and Williams, S.T. (1994): Bergey's Manual of Determinative Bacteriology, ninth ed., Williams \& Wilkins Comp., Baltimore, MD, USA.

Hou, C.T., Ahlgren, J.A., Brown, W. and Nicholson, J.J. (1996): Production of an extracellular polysaccharide by Agrobacterium sp DS3 NRRL 8-14297 isolated from soil. Journal of Industrial Microbiology 16: 129-133.

Hrmova, M., Taft, C.S., Selitrennikoff, C.P. (1989): $\beta$ (1, 3) - D-Glucan synthase of Neurospora crassa: Partial purification and characterization of solubilized enzyme activity. Exp. Mycol. 13, 129-139.

Jordon, D. C., (1984): Rhizobiaceae conn 1938. pages 234-256 in : Bergey's manual of systematic bacteriology, vol. 1, N. R. krieg, ed., Williams \& Wilkins Comp., Baltimore, Baltimore.

Karnezis, V., Fischer, H.C., Neumann, G.M., Stone, B.A., Stanisich, V.A. (2002): Cloning and characterization of the phosphatidylserine synthase gene of Agrobacterium sp. strain ATCC 31749 and effect of its inactivation on production of highmolecularmass $(1 \rightarrow 3)-\beta$-D-glucan (curdlan). J. Bacteriol. 184, 4114-4123.

Kerr, A.; Manigault, P.; and Tempe, J. (1977): Transfer of virulence in vivo and in vitro in Agrobacterium, Nature $265: 560-561$.

Kersters, K., and J. De Ley. (1984): Genus III. Agrobacterium Conn 1942, p. 244-254. In N. R. Krieg and J. G. Holt (ed.), Bergey's manual of systematic bacteriology, vol. 1. The Williams \& Wilkins Co., Baltimore.

Kim, B.; Sahin, N.; Minnikin, D.E.; Zakrzewska-Czerwinska, J.; Mordarski, M. and Goodfellow, M. (2004): Classification of thermophilic bacteria, including the description of Streptomyces thermoalcalitolerans sp. nov.. Int. J. Syst. Bacteriol. 49: 7-17.

Kudlicka, K., Brown, R.M. (1997): Cellulose and callose biosynthesis in higher plants. 1. Solubilization and separation of $(1,3)$ - and $(1,4)$ - $\beta$-glucan synthase activities from mung bean. Plant Physiol. 115, 643-656.

Larebeke .van, engler .G, Holsters. M, Van Den Elsacker. S, and Schell. J, (1974): Lage plasmid in Agrobacterium tumefaciens essential for crown gall - inducing ability. Nature 252: 169-170. 
Lee, J. W., W. G. Yeomans, A. F. Allen, D. L. Kaplan, F. Deng, and R. A. Gross (1997): Exopolymers from Curdlan production: incorporation of glucose-related sugars by Agrobacterium sp. strain ATCC 31749. Can. J. Microbiol. 43: 149-156.

Lee, J.H., Lee, I.Y.,( 2001): Optimization of uracil addition for curdlan (beta-glucan) production by Agrobacterium species. Biotechnol. Lett. 23, 1131-1134.

Leigh, J.A., Coplin, D.L. (1992): Exopolysaccharides in plant-microbe interactions. Annu. Rev. Microbiol. 46, 307-346.

Maria Hrmova \& Bruce A. Stone \& Geoffrey B. Fincher (2010): High-yield production, refolding and a molecular modeling of the catalytic module of $(1,3)-\beta$-D-glucan (curdlan) synthase from Agrobacterium sp. Glycoconj J, 27:461-476.

McIntosh, M., Stone, B.A., Stanisich, V.A., (2005): Curdlan and other bacterial (1 $\rightarrow 3)$ Beta glucans. Appl. Microbiol. Biotechnol. 68, 163-173.

Moore, L.W. Kado, C.I. Bouzar, H. (1988): Gram-negative bacteria A, Agrobacterium, In: N.W. Schaad (Ed.), Laboratory Guide for Identification of Plant Pathogenic Bacteria, American Phytopathological Society, St. Paul, MN , pp. 16-36.

Moscovici, M., Ionescu, C., Caraiani, T.; Cric, M.; Claudia M., Chescu,V., Ghera, G.; Gheorghiu, C., Stan, A., Soare, M., and Mardale, R. (2009): Curdlan- type polysaccharide obtained using a strain of Agrobacterium rhizogenes. Romanian Biotechnological Letters Vol. 14, No. 4, 2009, pp. 4530-4537.

Murugesan, S. Manoharan, C. Vijayakumar R. and Panneerselvam A. (2010): Isolation and Characterization of Agrobacterium rhizogenes, from the Root Nodules of Some Leguminous PlantsInternational Journal of Microbiological Research 1 (3): 92-96.

Nakanishi, K.; Kimura, K .; Kushi, S.; and Yamazaki, E. (1974): Complex formation of gel-forming bacterial (1 - 3)-Beta-D- glucans (curdlan-type polysaccharides) with dyes in aqueous solution. Carbohydrate Res 32: 47-52.

Nakanisih, I.; kimura, k.; Suzuki, T.; Ishikawa, M.; Banno, I.; Sakane, T.; and Harada T. (1976): Demonstration of curdlan-type polysaccharide and some other beta $(1,3)$ glucans in microorganisms with aniline blue. Journal of General and Applied Microbiology 22, 1-11.

Nelson, P. E.; Toussoun, T. A.; Marasas, W. F. O. (1983): An illustrated Manual for identification, the Pennsylvania State University Press University Park and London.

Oskay, M.; Tamer, A.U.; Azeri, C. (2004): Antibacterial activities of some actinomycetes isolated from farming soils of Turkey. African Journal of Biotechnology; 3 (9): 441-446.

Partridge, S.M. (1949): Improved spraying reagents for the detection of sugars on paper chromatograms; Nature, 164, 443.

Phillips KR, Lawford HG (1983): Curdlan: its properties and production in batch and continuous fermentations. In: Bushell DE (Ed) Progress in industrial microbiology, vol 18. Elsevier,Amsterdam, pp 201-229.

Roy, M. and M. Sasser. (1983): A medium selective for Agrobacterium tumefaciens biotype 3. Phytopathology 73: 810. 
Saitou, N., and Nei, M. (1987): The neighbor-joining method: a new method for reconstructing Phylogenetic trees. Mol. Biol. Vol., 4: 406-425.

Schaad, N.W., Jones J.B. and Chun, W. (2001): Laboratory Guide for Identification of Plant Pathogenic Bacteria, $3^{\text {rd }}$ Ed. APS Press, St. Paul, MN. pp. 17-35.

Soriful ,I. , Atikur ,R. , Mominul ,I., Mostafizur ,R., Abu Hena Mostofa ,J., Firoz,A., (2010): Maton. Agriculturae Conspectus Scientificus | Vol. 75 No. 3 (113-117).

Stasinopoulos, S.J., Fisher, P.R., Stone, B.A., Stanisich, V.A (1999): Detection of two loci involved in $(1 \rightarrow 3)-\beta$-glucan (curdlan) biosynthesis by Agrobacterium sp. ATCC 31749, and comparative sequence analysis of the putative curdlan synthase gene. Glycobiology 9, 31-41.

Stone, B.A., Clarke, A.E (1992): The chemistry and biochemistry of (1, 3)- $\beta$-glucans. La Trobe University Press Melbourne, Australia.

Stone, B.A., Jacobs, A.K., Hrmova, M., Burton, R.A., Fincher, G. B (2010): The biosynthesis of plant cell wall and related polysaccharides by enzymes of the GT2 and GT48 families. In: Ulvskov, P. (ed.) Plant Polysaccharides Series: Annual Plant Reviews. Blackwell, Danvers in the press.

Sutherland, I.W. (1993): Biosynthesis of Extracellular Polysaccharides. In: Industrial Gums, R.L. Whistler, J.N. BeMiller (Eds.), Academic Press, Inc., San Diego, CA, USA, pp. 69-85.

Taso, P.H., Leben,C., and Keitt, G.W. (1960): Phytopathology, 50:88-89.

USFDA (1996): 21 CFR 172-Food additives permitted for direct addition to food for human consumption: curdlan. Federal Register. USA. 61: 65941-5942.

Willems, A. Collins, M.D. (1993): Phylogenetic analysis of rhizobia and agrobacteria based on 16S rRNA gene sequences, Int. J. Syst. Bacteriol. 43 305-313.

Woese, C.R. (1987): Bacterial Evolution. Microbiological Reviews 51: 221-271.

Yotsuzuka, F., (2001): Curdlan. In: Cho SS, Dreher ML (eds). Handbook of dietary fiber. Dekker, New York, pp 737-757. 


\section{عزل وتعريف عزلات اجروبكتيريم مصريه جديده المنتجه للكيردلان}

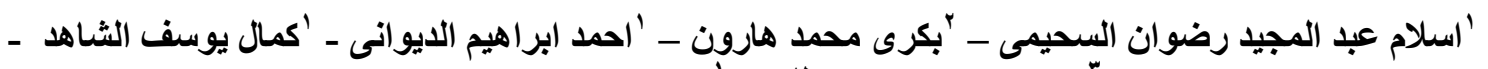

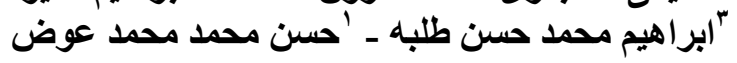

'قسم كيمياء المنتجات الطبيعيه و الميكروبيه المركز القومى للبحوث ـ ـقَم النبات و الميكروبيولوجى كليه العلوم جامعة

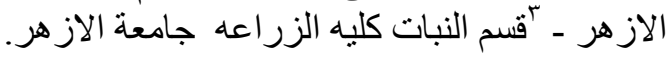

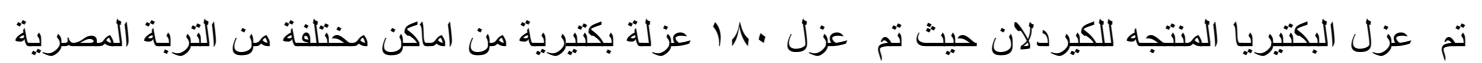

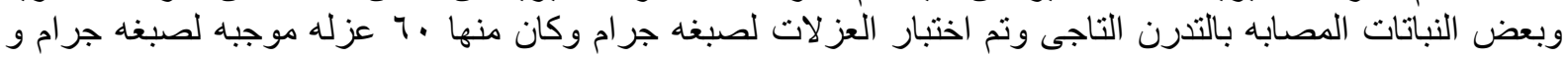

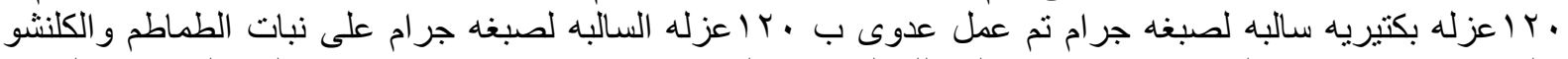

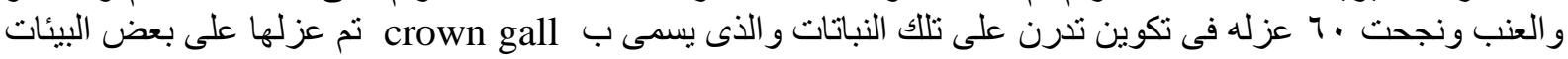

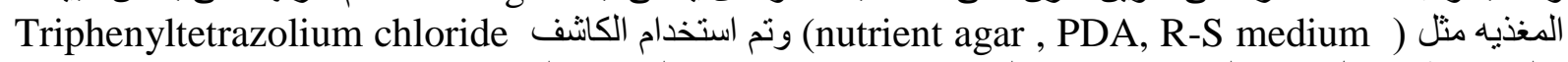
و الذى يعطى شكل مميز للاجروبكتيريم على R-S medium . تم الكثنف على وجنى وجود سكريات عديده باستحدام صبغيه

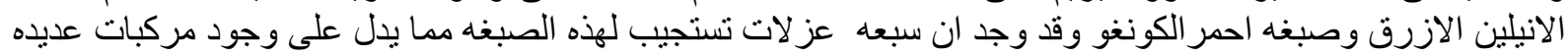

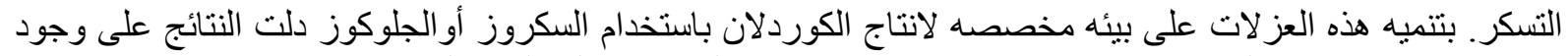

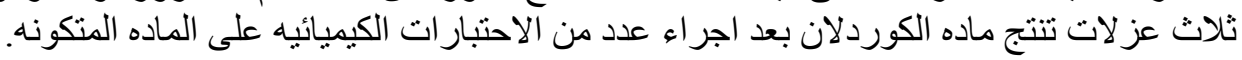

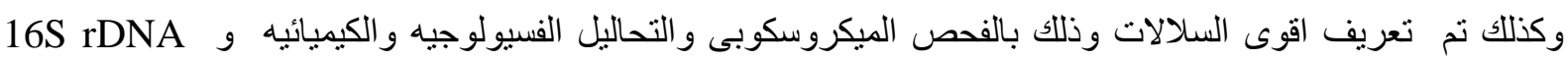
region of chromosomal DNA 